\title{
SERUM LIPOIDS AND PROTEINS IN HYPOTHYROIDISM 1
}

\author{
By E. F. GILDEA, E. B. MAN, AND J. P. PETERS \\ (From the Departments of Psychiatry and of Internal Medicine, Yale University, School of \\ Medicine, New Haven, and the Medical Service of the New Haven Hospital)
}

(Received for publication July 1, 1939)

Previous investigators $(1,2,3,4,5)$ have shown that a high serum cholesterol is commonly found in patients presenting the classical symptoms of myxedema. There has been a difference of opinion (6), however, as to whether high cholesterol invariably occurred and as to whether it was a sufficiently fundamental part of the syndrome to be of value in weeding out the atypical forms of hypothyroidism from the complex group of patients with low basal metabolic rates and such symptoms as retardation, weakness, easy fatigability, sensitivity to cold, falling hair, dry skin, obesity, etc. Certain authors, and particularly Hurxthal, have concluded that the level of cholesterol constitutes a valuable index of the degree of hypothyroidism, while others $(7,8,9,10)$ have found it unreliable and not an essential part of the syndrome. A contributing factor to this disagreement has been the difference in methods employed.

The basal metabolic rate has not proved to be an infallible criterion of hypothyroidism. For example, it may be low without the syndrome of sensitivity to cold, edema, dry skin and coarse hair, or the patient may be so tense and excitable that relaxation essential to the measurement of the true basal metabolic rate is impossible.

The present investigation was undertaken to study whether or not the levels of serum cholesterol, fatty acids, and phosphatides might furnish accurate criteria of thyroid deficiency and of the value of administering dessicated thyroid. A second purpose was to evaluate the effect of administering thyroid at the height of lipemia. Disorders in protein metabolism have been also described as occurring in myxedema, but the apparent changes in serum proteins may well have been compensatory responses to the disturbance in water metabolism. In order to obtain further insight into this problem, serum proteins and

1 This work was aided in part by a grant from the Knight Fund, Yale University School of Medicine. albumin and globulin fractions have been also investigated in these patients.

\section{MATERIALS AND METHODS}

In order to evaluate the significance of the level of lipoids in myxedema, as many as possible of the criteria of hypothyroidism have been utilized in the study of each patient. These criteria have been outlined under the categories of clinical symptoms, basal metabolic rate, height of serum total proteins as contrasted with serum cholesterol and other lipoids and proteins.

The following clinical symptoms have been considered indicative of hypothyroidism. Of first importance was the presence of edema, usually beginning as puffiness about the eyes. Dry skin and coarse dry hair associated with scanty eyebrows, general slowness of motor and mental activities, or more briefly retardation, and slow pulse have been considered significant. Subjective symptoms have, as always, proved difficult to evaluate. Sensitiveness to cold, complaints of easy fatigability and general weakness have been particularly considered.

$A$ basal metabolic rate below minus 20 per cent has been accepted as an essential criterion of classical myxedema. It has been recognized, however, that occasionally patients with clinical signs of myxedema that disappear promptly under thyroid therapy may not have such low basal metabolic rates.

Previous work has shown that serum proteins may be elevated in hypothyroidism. Values of 7.7 per cent (11) or higher have been considered as suggestive of hypothyroidism.

Cholesterol has been accepted as significantly above the normal limits for the method when the level was $300 \mathrm{mgm}$. per cent or more. This high figure has been chosen instead of $250 \mathrm{mgm}$. per cent, the upper limit for the majority of people in good health, because 5 out of 100 of these nor- 
mals have been found to have cholesterols between 250 and $300 \mathrm{mgm}$. per cent.

The essential test of the dependence of any of the above phenomena on deficient thyroid activity was sought in their response to administration of dessicated thyroid. In view of the observation of other workers that the symptoms of hypothyroidism respond promptly to small doses of thyroid, usually 1 to 2 grains daily, the symptoms which did not change after the administration of 2 to 3 grains daily for 2 to 3 weeks were not accepted as necessarily due to thyroid deficiency. In 4 patients who had responded promptly to thyroid therapy, it was possible to discontinue the drug. The reversion of symptoms-basal metabolic rate, lipoids and proteins-to their former levels, was accepted as conclusive evidence of their dependence on the amount of thyroid hormone in the body.

The basal metabolic rates were determined with Collins' Benedict-Roth or Sanborn's motorgrafic modification of the Benedict apparatus. Blood was drawn without stasis from the antecubital vein when the patient was in the post-absorptive state before breakfast. Serum proteins (12), cholesterol $(13,14)$, lipoid phosphorus $(15,14)$ and titrated fatty acids $(16,17)$ were determined by methods previously described.

A summary of the clinical status of each patient has been presented in tabular form along with the chemical data. Unfortunately, many individual distinctions between the patients have been lost in this process, but much has been gained thereby in brevity and clarity. The term edema has been used in the tables somewhat improperly. In point of fact it refers to the characteristic myxedema but this latter term has been applied to the whole clinical picture instead of the symptom which it designates. Minor degrees of puffiness of skin about the eyes have been graded as one + in the column for edema and more marked amounts as ++ . Three +++ have been employed for marked puffiness about the eyes and also over hands and feet. No patients, however, had the extreme degrees of edema described in the classical myxedema of the text books. Degrees of dryness and roughness of skin and hair, while consistent features of the syndrome, proved more difficult to quantitate than the amount of edema. The term retardation has been used to denote an obvious slowing of patients' motor activities. Mental retardation was estimated from the rate of response to questions and in some patients on the basis of reports of inability to do customary tasks in the usual time. Degrees of aches and pains and sensitivity to cold were necessarily evaluated according to patients' statements. Four groups of patients have been differentiated on the basis of the above symptoms, basal metabolic rates, and response to thyroid.

\section{Data}

The basal metabolic rate, serum cholesterol, titrated fatty acids, lipoid phosphorus, total proteins, including albumin and globulin fractions, were studied at frequent intervals in 29 patients before, during and after treatment with thyroid. In presenting the results many of these data have been omitted and only the basal metabolic rate, cholesterol and protein studies illustrating the values without treatment and the maximum change produced by thyroid therapy have been included in Tables I, II, III and IV. The patients in the first part of each table, marked by (T), had had one or more thyroidectomies. The sex and age of each subject are given under the patient's hospital number. Armour's or Wyeth's U.S.P. dessicated thyroid was used throughout and the amounts refer to these products. The recorded quantity of thyroid refers to the daily dosage that the patient had been receiving for a period of at least 2 weeks before the examination.

Group I, Table I, contains 5 patients with the symptoms of myxedema and basal metabolic rates below minus 20 per cent. Two had previous thyroidectomies, A45359 and A43137. Striking clinical improvement followed the administration of 1 grain of thyroid per day to 2 patients and 2 grains per day to the 3 other patients. Striking clinical improvement implies disappearance of edema, restoration of skin and hair, increased speed of activity and of energy, and return of feeling of well-being. The approximate degrees of these changes have been indicated by the plus signs in the table.

Group 2, Table II, contains 11 patients with most of the symptoms of myxedema, but who either did not have basal metabolic rates below minus 20 per cent, or had complicating disorders. Thyroid treatment was followed by recovery. 
TABLE I

Patients with symptoms of myxedema and basal metabolic rates below minus 20 per cent; recovery after thyroid administration

\begin{tabular}{|c|c|c|c|c|c|c|c|c|c|c|c|c|c|c|}
\hline \multirow{2}{*}{$\begin{array}{c}\text { Number. } \\
\text { sex and } \\
\text { age }\end{array}$} & \multirow{2}{*}{$\begin{array}{l}\text { Thy- } \\
\text { roid } \\
\text { doee }\end{array}$} & \multirow{2}{*}{ Edema } & \multirow{2}{*}{ Weight } & \multirow{2}{*}{ Pulse } & \multirow{2}{*}{$\begin{array}{l}\text { Dry } \\
\text { akin }\end{array}$} & \multirow{2}{*}{$\begin{array}{c}\text { Coarse } \\
\text { and } \\
\text { thin } \\
\text { hair }\end{array}$} & \multicolumn{2}{|c|}{ Retardation } & \multirow{2}{*}{$\underset{\text { Weaks }}{\text { Weak- }}$} & \multirow{2}{*}{$\begin{array}{c}\text { Pain and } \\
\text { aches in } \\
\text { muscles } \\
\text { and } \\
\text { joints }\end{array}$} & \multirow{2}{*}{$\begin{array}{l}\text { Sensi- } \\
\text { tivity } \\
\text { to cold }\end{array}$} & \multirow{2}{*}{$\begin{array}{c}\text { Baeal } \\
\text { metab- } \\
\text { oliam }\end{array}$} & \multirow{2}{*}{ 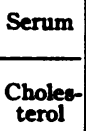 } & \multirow{2}{*}{$\begin{array}{l}\text { Pro- } \\
\text { tein }\end{array}$} \\
\hline & & & & & & & Phyd- & $\underset{\text { tal }}{\text { Men- }}$ & & & & & & \\
\hline years & $\begin{array}{c}\text { grains } \\
\text { per } \\
\text { day }\end{array}$ & & $\begin{array}{l}\text { kilo- } \\
\text { erams }\end{array}$ & & & & & & & & & $\begin{array}{l}\text { per } \\
\text { cent }\end{array}$ & $\begin{array}{c}\text { mgm. } \\
p e r \\
100 \\
10 c .\end{array}$ & \begin{tabular}{|l} 
per \\
cent
\end{tabular} \\
\hline $\begin{array}{l}\text { A45359 } \\
\text { F } 61(T)\end{array}$ & $\begin{array}{l}0 \\
1\end{array}$ & $t_{0}^{+}$ & $\begin{array}{l}52.0 \\
59.0\end{array}$ & $\begin{array}{l}70 \\
80\end{array}$ & $+\frac{+}{0}+$ & $+\underset{0}{++}$ & $+\underset{0}{++}$ & $+\underset{0}{+t}$ & $\begin{array}{c}+t \\
+\end{array}$ & $t_{0}^{+}$ & $+\underset{0}{++}$ & $\begin{array}{l}-27 \\
+4\end{array}$ & $\begin{array}{l}603 \\
275\end{array}$ & $\begin{array}{l}8.1 \\
7.1\end{array}$ \\
\hline $\begin{array}{l}\text { A43137 } \\
\mathrm{F} \quad 38(\mathrm{~T})\end{array}$ & $\begin{array}{l}0 \\
2\end{array}$ & + & $\begin{array}{l}69.1 \\
67.8\end{array}$ & $\begin{array}{l}80 \\
86\end{array}$ & ++ & $\underset{0}{++}$ & $\underset{0}{++}$ & $\begin{array}{c}++ \\
+\end{array}$ & $++t$ & $\begin{array}{l}\mathbf{0} \\
\mathbf{0}\end{array}$ & $\underset{0}{++}$ & $\begin{array}{l}-21 \\
-2\end{array}$ & $\begin{array}{l}342 \\
201\end{array}$ & $\begin{array}{l}8.1 \\
6.7\end{array}$ \\
\hline $\begin{array}{r}\text { A62475 } \\
\text { F } 21\end{array}$ & $\begin{array}{l}\mathbf{0} \\
2\end{array}$ & $+\underset{0}{++}$ & $\begin{array}{l}60.0 \\
57.0\end{array}$ & $\begin{array}{l}60 \\
62\end{array}$ & $\underset{0}{++}$ & $\underset{0}{++}$ & +++ & $\begin{array}{c}++ \\
+\end{array}$ & ++ & $+t_{0}^{+}$ & $\underset{0}{++}$ & $\begin{array}{l}-31 \\
-14\end{array}$ & $\begin{array}{l}335 \\
176\end{array}$ & $\begin{array}{l}7.1 \\
6.9\end{array}$ \\
\hline $\begin{array}{r}\text { A58944 } \\
\text { F } 49\end{array}$ & $\begin{array}{l}0 \\
2\end{array}$ & $\underset{0}{++}$ & $\begin{array}{l}98.3 \\
84.9\end{array}$ & $\begin{array}{l}60 \\
62\end{array}$ & $+\underset{0}{++}$ & $+\underset{0}{++}$ & $\underset{0}{++}$ & $+_{0}^{+}$ & $\begin{array}{c}++ \\
0\end{array}$ & $\underset{+}{++}$ & $t_{0}^{+}$ & $\begin{array}{l}-30 \\
-16\end{array}$ & $\begin{array}{l}387 \\
250\end{array}$ & $\begin{array}{l}7.6 \\
6.8\end{array}$ \\
\hline $\begin{array}{r}A 52821 \\
F \quad 62\end{array}$ & $\begin{array}{l}0 \\
1\end{array}$ & $+\underset{0}{+}+$ & $\begin{array}{l}67.6 \\
63.4\end{array}$ & $\begin{array}{c}60 \\
52-115\end{array}$ & $\underset{0}{++}+$ & $+\underset{0}{+}+$ & $t_{0}^{+}$ & $+_{0}^{+}$ & $\underset{0}{++}$ & $+\underset{0}{++}+$ & $+_{0}^{+}$ & $\begin{array}{l}-31 \\
-1\end{array}$ & $\begin{array}{l}550 \\
241\end{array}$ & \begin{tabular}{|l|}
8.4 \\
8.0
\end{tabular} \\
\hline
\end{tabular}

(T) Previous thyroidectomy.

TABLE II

Patients with a number of symptoms of myxedema but presenting some atypical features; recovery after thyroid administration

\begin{tabular}{|c|c|c|c|c|c|c|c|c|c|c|c|c|c|c|}
\hline \multirow{2}{*}{$\begin{array}{c}\text { Number. } \\
\text { ex and } \\
\text { age }\end{array}$} & \multirow{2}{*}{$\begin{array}{l}\text { Thy- } \\
\text { roid } \\
\text { doee }\end{array}$} & \multirow{2}{*}{ Edema } & \multirow{2}{*}{ Weight } & \multirow{2}{*}{ Pulee } & \multirow{2}{*}{$\begin{array}{l}\text { Dry } \\
\text { oktin }\end{array}$} & \multirow{2}{*}{$\begin{array}{l}\text { Coarse } \\
\text { and } \\
\text { thin } \\
\text { hair }\end{array}$} & \multicolumn{2}{|c|}{ Retardation } & \multirow{2}{*}{$\begin{array}{c}\text { Weak- } \\
\text { ness }\end{array}$} & \multirow{2}{*}{$\begin{array}{l}\text { Pain and } \\
\text { aches in } \\
\text { muscles } \\
\text { and } \\
\text { joints }\end{array}$} & \multirow{2}{*}{$\begin{array}{l}\text { Sensi- } \\
\text { tivity } \\
\text { to cold }\end{array}$} & \multirow{2}{*}{$\begin{array}{c}\text { Basal } \\
\text { metab- } \\
\text { oliam }\end{array}$} & \multirow{2}{*}{$\begin{array}{l}\text { Serum } \\
\begin{array}{c}\text { Choles } \\
\text { terol }\end{array} \\
\end{array}$} & \multirow{2}{*}{$\begin{array}{l}\text { Pro- } \\
\text { tein }\end{array}$} \\
\hline & & & & & & & Phyd- & $\underset{\text { tal }}{\text { Men- }}$ & & & & & & \\
\hline years & $\begin{array}{l}\text { srains } \\
\text { per } \\
\text { day }\end{array}$ & & $\begin{array}{c}\text { kilo- } \\
\text { grams }\end{array}$ & & & & & & & & & $\begin{array}{l}\text { per } \\
\text { cent }\end{array}$ & $\begin{array}{l}\text { mgm. } \\
\text { per } \\
100 \text { cc. }\end{array}$ & $\begin{array}{l}\text { per } \\
\text { cent }\end{array}$ \\
\hline $\begin{array}{l}\text { A56471 } \\
\text { F } 37(T)\end{array}$ & $\begin{array}{l}0 \\
1\end{array}$ & $\begin{array}{l}0 \\
0\end{array}$ & $\begin{array}{l}61.0 \\
64.0\end{array}$ & $\begin{array}{l}70 \\
80\end{array}$ & $+t$ & & $\stackrel{+}{0}$ & $\stackrel{+}{0}$ & $\begin{array}{c}++ \\
+\end{array}$ & $\begin{array}{l}+ \\
0\end{array}$ & $\underset{0}{++}$ & $\begin{array}{l}-17^{*} \\
+1\end{array}$ & $\begin{array}{l}435 \\
275\end{array}$ & $\begin{array}{l}8.4 \\
7.4\end{array}$ \\
\hline$\underset{F}{A 46085} 5(T)$ & $\begin{array}{l}0 \\
1\end{array}$ & $\underset{0}{++}$ & $\begin{array}{l}50.3 \\
50.0\end{array}$ & $\begin{array}{l}64 \\
80\end{array}$ & $t_{0}^{+}$ & $\underset{0}{++}$ & $t_{0}^{+}$ & $t_{0}^{+}$ & $\underset{+}{+t}$ & $\begin{array}{l}0 \\
0\end{array}$ & & $\begin{array}{l}-16 \\
+11\end{array}$ & $\begin{array}{l}532 \\
245\end{array}$ & $\begin{array}{l}7.1 \\
5.3\end{array}$ \\
\hline$F^{54183} 63(T)$ & $\begin{array}{l}0 \\
1 \frac{1}{2}\end{array}$ & $\begin{array}{l}\mathbf{0} \\
\mathbf{0}\end{array}$ & $\begin{array}{l}61.0 \\
55.1\end{array}$ & $\begin{array}{l}58 \\
68\end{array}$ & $\begin{array}{c}++ \\
+\end{array}$ & + & ++ & $\begin{array}{l}++ \\
+\end{array}$ & $\begin{array}{c}++ \\
+\end{array}$ & & $\begin{array}{c}++ \\
+\end{array}$ & $\begin{array}{l}-24 \\
-3\end{array}$ & $\begin{array}{l}532 \\
355\end{array}$ & $\begin{array}{l}7.5 \\
7.2\end{array}$ \\
\hline$F^{10670}$ & $\begin{array}{l}0 \\
1\end{array}$ & $\begin{array}{l}\mathbf{0} \\
\mathbf{0}\end{array}$ & $\begin{array}{l}58.0 \\
56.5\end{array}$ & $\begin{array}{l}52 \\
98\end{array}$ & $\begin{array}{c}++ \\
+\end{array}$ & ++ & $\stackrel{+}{0}$ & $t_{0}^{+}$ & $\stackrel{+}{0}$ & $\begin{array}{l}\mathbf{0} \\
\mathbf{0}\end{array}$ & $t_{0}^{+}$ & -6 & $\begin{array}{l}343 \\
208\end{array}$ & $\begin{array}{l}7.4 \\
7.0\end{array}$ \\
\hline $\begin{array}{l}\text { A39091 } \\
\text { F } 42(T)\end{array}$ & $\begin{array}{l}0 \\
\frac{1}{3}\end{array}$ & $\begin{array}{c}+t \\
+\end{array}$ & $\begin{array}{l}72.0 \\
75.5\end{array}$ & $\begin{array}{l}66 \\
96\end{array}$ & $+_{0}^{+}$ & + & $\begin{array}{c}++ \\
+\end{array}$ & & $\begin{array}{c}+++ \\
++\end{array}$ & $\begin{array}{l}\mathbf{0} \\
\mathbf{0}\end{array}$ & $+\underset{0}{++}$ & -1 & $\begin{array}{l}407 \\
201\end{array}$ & $\begin{array}{l}7.5 \\
7.9\end{array}$ \\
\hline $\begin{array}{l}\mathrm{A} 33872 \\
\mathrm{~F} \quad 41(\mathrm{~T})\end{array}$ & $\begin{array}{l}0 \\
1\end{array}$ & $\underset{t}{+t}$ & $\begin{array}{l}65.5 \\
68.0\end{array}$ & $\begin{array}{l}80 \\
80\end{array}$ & ++ & $\begin{array}{l}++ \\
++\end{array}$ & $\begin{array}{c}++ \\
+\end{array}$ & $\begin{array}{c}++ \\
+\end{array}$ & $\begin{array}{c}++ \\
+\end{array}$ & $\begin{array}{l}\mathbf{0} \\
\mathbf{0}\end{array}$ & & $\begin{array}{l}-18 \\
+9\end{array}$ & $\begin{array}{l}741 \\
468\end{array}$ & $\begin{array}{l}7.4 \\
7.0\end{array}$ \\
\hline $\begin{array}{l}\mathrm{A} 67142 \\
\mathrm{M} \quad 33(\mathrm{~T})\end{array}$ & $\begin{array}{l}0 \\
1\end{array}$ & $+\underset{0}{+t}$ & $\begin{array}{l}76.2 \\
71.8\end{array}$ & $\begin{array}{l}60 \\
72\end{array}$ & $t_{0}^{+}$ & & $\begin{array}{c}++ \\
+\end{array}$ & $t_{0}^{+}$ & ++ & $\begin{array}{l}\mathbf{0} \\
\mathbf{0}\end{array}$ & $\begin{array}{c}++ \\
+\end{array}$ & $\begin{array}{l}-18 \\
+4\end{array}$ & $\begin{array}{l}612 \\
275\end{array}$ & $\begin{array}{l}6.5 \\
6.0\end{array}$ \\
\hline $\begin{array}{l}\mathrm{P} 1536 \\
\mathrm{~F} \quad 45(\mathrm{~T})\end{array}$ & $\begin{array}{l}0 \\
1\end{array}$ & $+\underset{0}{++}$ & $\begin{array}{l}53.5 \\
45.0\end{array}$ & $\begin{array}{r}110 \\
90\end{array}$ & $\begin{array}{c}++ \\
++\end{array}$ & $\begin{array}{c}+++ \\
++\end{array}$ & + & + & $\begin{array}{c}++ \\
++\end{array}$ & $\begin{array}{l}\mathbf{0} \\
\mathbf{0}\end{array}$ & $\begin{array}{c}++ \\
+\end{array}$ & $\begin{array}{l}-21 \\
+7\end{array}$ & $\begin{array}{l}680 \\
336\end{array}$ & $\begin{array}{l}6.2 \\
6.0\end{array}$ \\
\hline $\begin{array}{l}\text { A78256 } \\
\text { F } 19(T)\end{array}$ & $\begin{array}{l}0 \\
1\end{array}$ & $\begin{array}{l}0 \\
0\end{array}$ & $\begin{array}{l}70.7 \\
66.6\end{array}$ & $\begin{array}{l}70 \\
80\end{array}$ & $\stackrel{+}{0}$ & $\stackrel{+}{0}$ & $\stackrel{+}{0}$ & $\stackrel{+}{0}$ & + & $\begin{array}{l}0 \\
0\end{array}$ & $\begin{array}{l}\mathbf{0} \\
\mathbf{0}\end{array}$ & $\begin{array}{l}-23 \\
+2\end{array}$ & $\begin{array}{l}383 \\
158\end{array}$ & $\begin{array}{l}8.0 \\
7.3\end{array}$ \\
\hline$F^{1} 41$ & $\begin{array}{l}0 \\
2 \frac{1}{2}\end{array}$ & $\begin{array}{l}\mathbf{0} \\
\mathbf{0}\end{array}$ & $\begin{array}{l}67.4 \\
64.3\end{array}$ & $\begin{array}{l}70 \\
86\end{array}$ & $t_{0}^{+}$ & $t_{0}^{+}$ & $\stackrel{+}{0}$ & + & + & $\begin{array}{l}0 \\
0\end{array}$ & + & $\begin{array}{l}-26 \\
+6\end{array}$ & $\begin{array}{l}330 \\
145\end{array}$ & $\begin{array}{l}6.1 \\
5.4\end{array}$ \\
\hline$F^{85071} 52$ & $\begin{array}{l}0 \\
2\end{array}$ & $\begin{array}{l}\mathbf{0} \\
\mathbf{0}\end{array}$ & $\begin{array}{l}65.0 \\
65.0\end{array}$ & $\begin{array}{l}70 \\
68\end{array}$ & $\begin{array}{l}0 \\
\mathbf{0}\end{array}$ & $\begin{array}{l}\mathbf{0} \\
\mathbf{0}\end{array}$ & $\begin{array}{l}++ \\
++\end{array}$ & $\begin{array}{l}++ \\
++\end{array}$ & ++ & $\begin{array}{c}+++ \\
++\end{array}$ & & $\begin{array}{l}-26 \\
-8\end{array}$ & $\begin{array}{l}315 \\
211\end{array}$ & $\begin{array}{l}8.3 \\
7.0\end{array}$ \\
\hline
\end{tabular}

(T) Previous thyroidectomy.

- Unsatisfactory. 
Only 5, 54183, P1536, A78256, 1, and 85071 had basal metabolic rates below minus 20 per cent. Patient A39091 had hypertensive cardiovascular disease with decompensation, thereby making the results of basal metabolic rate determinations of uncertain clinical significance. Furthermore, on account of the cardiac condition the thyroid therapy was not pushed to the point of complete disappearance of symptoms attributable to hypothyroidism. Patient A67142 had had an acute nephritis following picric acid treatment of severe sunburn at about the time symptoms of hyperthyroidism were noted. The nephritis cleared up partially and he did well after thyroidectomy until 3 months later when the symptoms of myxedema, noted in Table II, appeared. At this time some of the edema and weakness might have been due to the chronic nephritis which persisted. Patient 1536 also had a mild chronic nephritis probably secondary to a former chronic pyelitis. All of the 11 patients in this group were relieved of most of the symptoms attributed to hypothyroidism by $1 / 2$ to $2 \frac{1}{2}$ grains of thyroid daily. One, 85071 , was extremely slow in recovering on thy- roid therapy. This patient, a woman, was a poor informant of low intelligence who also had mild diabetes. Such complaints as weakness, pains and aches, mental and physical retardation, were difficult to evaluate. She obtained some relief on thyroid therapy. A subsequent course on placebos gave similar results. More recently, however, a longer period of thyroid therapy resulted in more convincing evidence of increasing strength, motor speed, and general improvement.

Group 3, Table III, includes patients with only some symptoms suggesting myxedema, but with basal metabolic rates below minus 20 per cent. The analysis of the symptoms reveals, however, that none had edema, that changes in the skin were absent or moderate in degree, and that only one complained of sensitivity to cold. The administration of thyroid produced little improvement in these patients, even when the daily dose was 4 or 5 grains.

In Table IV are 6 patients who suffered from a miscellaneous variety of symptoms but they all had in common incapacitating weakness and multiple pains and aches. Some had low basal

TABLE III

Patients with basal metabolic rates below minus 20 per cent and a few symptoms suggestive of myxedema; not improved by thyroid administration

\begin{tabular}{|c|c|c|c|c|c|c|c|c|c|c|c|c|c|c|}
\hline \multirow{2}{*}{$\begin{array}{l}\text { Number, } \\
\text { sex and } \\
\text { age }\end{array}$} & \multirow{2}{*}{$\begin{array}{l}\text { Thy- } \\
\text { roid } \\
\text { dose }\end{array}$} & \multirow{2}{*}{ Edema } & \multirow{2}{*}{ Weight } & \multirow{2}{*}{ Pulse } & \multirow{2}{*}{$\begin{array}{l}\text { Dry } \\
\text { skin }\end{array}$} & \multirow{2}{*}{$\begin{array}{l}\text { Coarse } \\
\text { and } \\
\text { thin } \\
\text { hair }\end{array}$} & \multicolumn{2}{|c|}{ Retardation } & \multirow{2}{*}{$\begin{array}{c}\text { Weak- } \\
\text { ness }\end{array}$} & \multirow{2}{*}{$\begin{array}{c}\text { Pain and } \\
\text { aches in } \\
\text { muscles } \\
\text { and } \\
\text { joints }\end{array}$} & \multirow{2}{*}{$\begin{array}{l}\text { Sensi- } \\
\text { tivity } \\
\text { to cold }\end{array}$} & \multirow{2}{*}{$\begin{array}{c}\text { Basal } \\
\text { metab- } \\
\text { olism }\end{array}$} & \multirow{2}{*}{$\frac{\text { Serum }}{\begin{array}{c}\text { Choles } \\
\text { terol }\end{array}}$} & \multirow{2}{*}{$\begin{array}{l}\text { Pro- } \\
\text { tein }\end{array}$} \\
\hline & & & & & & & $\begin{array}{c}\text { Physi- } \\
\text { cal }\end{array}$ & $\underset{\text { tal }}{\text { Men- }}$ & & & & & & \\
\hline years & $\begin{array}{c}\text { grains } \\
\text { per } \\
\text { day }\end{array}$ & & $\begin{array}{c}\text { kilo- } \\
\text { grams }\end{array}$ & & & & & & & & & $\begin{array}{l}\text { per } \\
\text { cent }\end{array}$ & $\begin{array}{c}\text { mgm. } \\
\text { per } \\
100 \text { cc. }\end{array}$ & $\begin{array}{l}\text { per } \\
\text { cent }\end{array}$ \\
\hline $\begin{array}{l}\text { A59140 } \\
\text { F } 27(T)\end{array}$ & $\begin{array}{l}0 \\
2 \frac{1}{2}\end{array}$ & $\begin{array}{l}\mathbf{0} \\
\mathbf{0}\end{array}$ & $\begin{array}{l}67.0 \\
67.5\end{array}$ & $\begin{array}{l}54 \\
70\end{array}$ & $\begin{array}{l}0 \\
0\end{array}$ & $\begin{array}{l}0 \\
0\end{array}$ & $\stackrel{+}{0}$ & $\stackrel{+}{+}$ & + & $\begin{array}{l}++ \\
+\end{array}$ & $\begin{array}{c}++ \\
+\end{array}$ & $\begin{array}{l}-26 \\
-8\end{array}$ & $\begin{array}{l}149 \\
114\end{array}$ & $\begin{array}{l}6.1 \\
5.7\end{array}$ \\
\hline $\begin{array}{l}\mathrm{A} 44014 \\
\mathrm{~F} \quad 39(\mathrm{~T})\end{array}$ & $\begin{array}{l}0 \\
4\end{array}$ & $\begin{array}{l}\mathbf{0} \\
\mathbf{0}\end{array}$ & $\begin{array}{l}83.0 \\
92.0\end{array}$ & $\begin{array}{l}54 \\
64\end{array}$ & $+\dot{+}$ & $\begin{array}{l}++ \\
++\end{array}$ & + & + & + & ++ & $\begin{array}{l}\mathbf{0} \\
\mathbf{0}\end{array}$ & $\begin{array}{l}-31 \\
-10\end{array}$ & $\begin{array}{l}204 \\
156\end{array}$ & $\begin{array}{l}6.7 \\
6.3\end{array}$ \\
\hline$F^{5} 50$ & $\begin{array}{l}0 \\
5\end{array}$ & $\begin{array}{l}\mathbf{0} \\
\mathbf{0}\end{array}$ & $\begin{array}{l}80.0 \\
74.0\end{array}$ & & & & + & + & $\begin{array}{l}++ \\
++\end{array}$ & $\begin{array}{c}+++ \\
++\end{array}$ & & $\begin{array}{l}-20 \\
+1\end{array}$ & $\begin{array}{l}258 \\
157\end{array}$ & $\begin{array}{l}7.0 \\
6.5 \\
\end{array}$ \\
\hline $\begin{array}{r}5253 \\
F^{49}\end{array}$ & $\begin{array}{l}0 \\
4\end{array}$ & $\begin{array}{l}\mathbf{0} \\
\mathbf{0}\end{array}$ & $\begin{array}{l}64.0 \\
66.5\end{array}$ & $\begin{array}{l}60 \\
86\end{array}$ & $\begin{array}{l}++ \\
++\end{array}$ & + & + & $\begin{array}{l}\mathbf{0} \\
\mathbf{0}\end{array}$ & ++ & $\begin{array}{l}+++ \\
++\end{array}$ & & $\begin{array}{l}-27 \\
-1\end{array}$ & $\begin{array}{l}252 \\
171\end{array}$ & $\begin{array}{l}5.9 \\
5.9\end{array}$ \\
\hline $\begin{array}{l}\mathrm{P} 1667 \\
\mathrm{~F} \quad 52\end{array}$ & $\begin{array}{l}0 \\
4 \dagger\end{array}$ & $\begin{array}{l}\mathbf{0} \\
\mathbf{0}\end{array}$ & $\begin{array}{l}50.0 \\
47.0\end{array}$ & $\begin{array}{l}75 \\
75 \\
\end{array}$ & $\begin{array}{l}0 \\
0\end{array}$ & ++ & $+++^{*}$ & ++ & $\begin{array}{l}++t \\
++t\end{array}$ & $\begin{array}{l}\mathbf{0} \\
\mathbf{0}\end{array}$ & $\begin{array}{l}\mathbf{0} \\
\mathbf{0}\end{array}$ & $\begin{array}{r}-38 \\
+\quad 1 \\
\end{array}$ & $\begin{array}{l}300 \\
119 \\
\end{array}$ & $\begin{array}{l}7.0 \\
6.4 \\
\end{array}$ \\
\hline$\stackrel{M}{ }^{2} 35$ & $\begin{array}{l}\mathbf{0} \\
\mathbf{2}\end{array}$ & $\begin{array}{l}\mathbf{0} \\
\mathbf{0}\end{array}$ & $\begin{array}{l}97.0 \\
97.0\end{array}$ & $\begin{array}{l}60 \\
60\end{array}$ & + & + & + & $\begin{array}{l}0 \\
0\end{array}$ & + & $\begin{array}{l}0 \\
0\end{array}$ & $\begin{array}{l}\mathbf{0} \\
\mathbf{0}\end{array}$ & $\begin{array}{l}-23 \\
-3\end{array}$ & $\begin{array}{l}222 \\
180\end{array}$ & $\begin{array}{l}6.9 \\
6.4\end{array}$ \\
\hline $\mathrm{M}^{6} 42$ & $\begin{array}{l}0 \\
4\end{array}$ & $\begin{array}{l}0 \\
0\end{array}$ & $\begin{array}{l}72.2 \\
75.4\end{array}$ & 74 & $\begin{array}{l}\mathbf{0} \\
\mathbf{0}\end{array}$ & $\begin{array}{l}\mathbf{0} \\
\mathbf{0}\end{array}$ & ++ & + & + & $\begin{array}{l}\mathbf{0} \\
\mathbf{0}\end{array}$ & $\begin{array}{l}0 \\
0\end{array}$ & $\begin{array}{l}-22 \\
-1\end{array}$ & $\begin{array}{r}149 \\
94\end{array}$ & $\begin{array}{l}6.6 \\
5.9\end{array}$ \\
\hline
\end{tabular}

(T) Previous thyroidectomy.

* Psychosis with alternating apathy and excitement.

† Thyroxin equivalent to 4 grains thyroid. 
TABLE IV

Patients with low basal metabolic rates with weakness and multiple complaints; not improved by thyroid administration

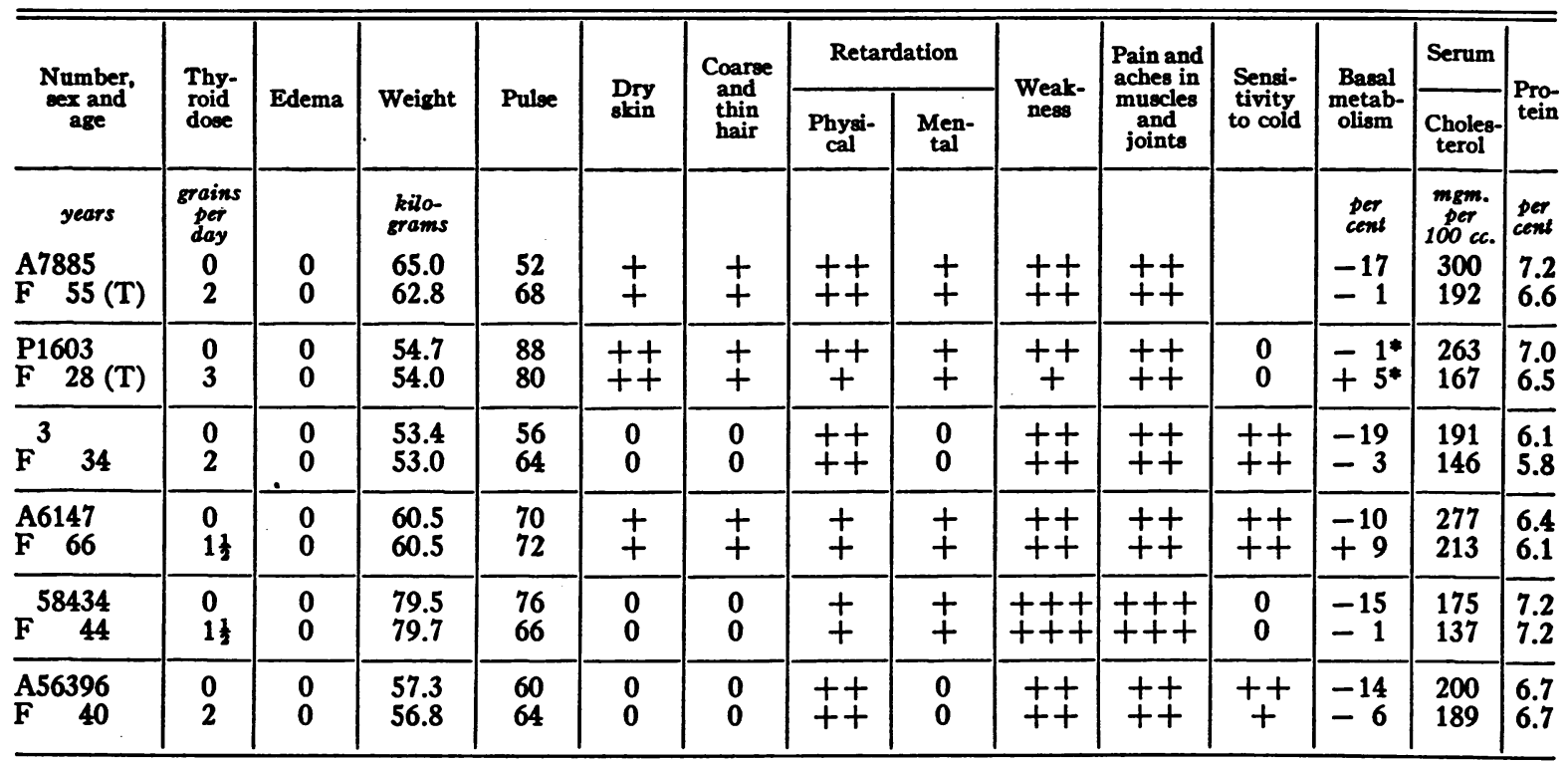

(T) Previous thyroidectomy.

* Unsatisfactory.

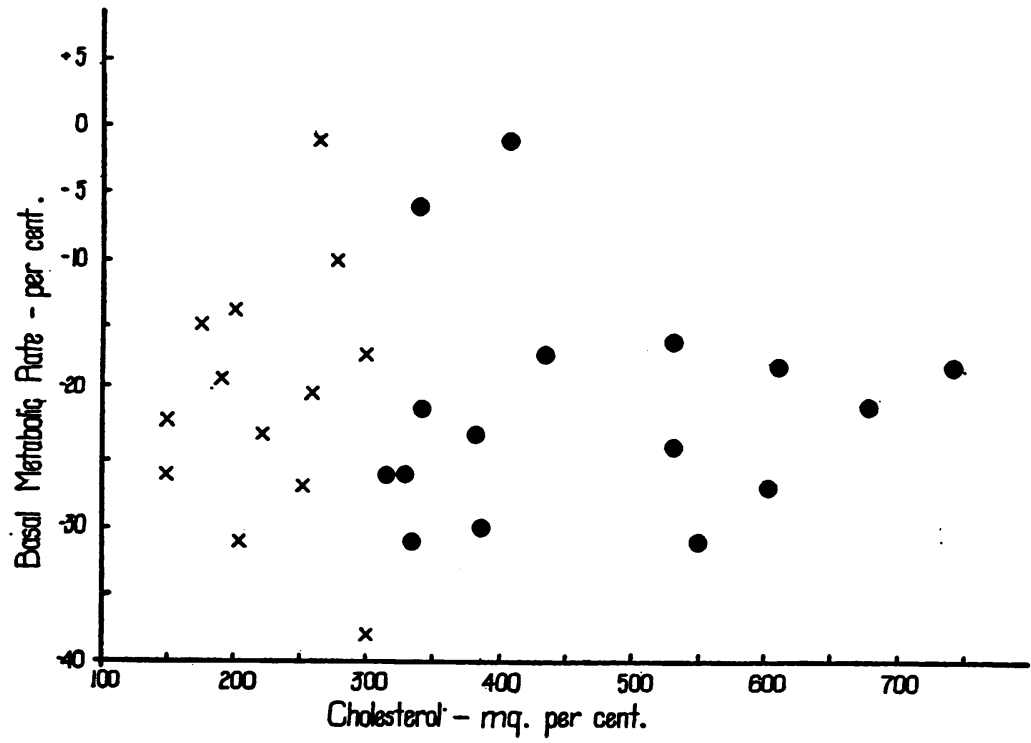

Fig. 1. Basal Metabolic Rate and Serum Cholesterol as Indicators of Subsequent ThyroId Therapy

Circles indicate values in patients before treatment who improved on thyroid therapy.

Crosses indicate values in patients before treatment who did not improve on thyroid therapy.

metabolic rates. Two were moderately obese (A6147, 58434). Two had had previous thyroidectomies. Their initial basals, with the exception of P1603, ranged from minus 10 to minus 19 per cent. They experienced no, or only slight, subjective improvement with thyroid administration.

The following figures have been employed to demonstrate relationships which could not be readily illustrated in tables. Figure 1 shows the 
relation of basal metabolic rate to the level of serum cholesterol before the administration of thyroid. Circles have been used to represent the 16 patients who improved with thyroid administration and who are listed in Tables I and II. Crosses have been used for the patients who were not definitely relieved of most of the symptoms by thyroid administration and who are listed in Tables III and IV. Figure 2 demonstrates the direction and degree of change in cholesterol and basal metabolic rate in the 29 patients. Figure 3 shows the relationship of serum cholesterol to lipoid phosphorus in 182 studies. All the determinations have been included. Circles represent the blood studies before, solid ones the blood studies after thyroid administration, crosses giving maximum results. In Figure 4 all of the 214 cholesterol studies have been plotted against fatty acids in order to illustrate the relationship between these substances.
In order to compare in detail the relative changes in basal metabolic rate, lipoids, proteins, weight and clinical symptoms of myxedema before and after treatment, individual figures 5,6 , 7,8 and 9 have been made for 5 patients in group 1. These figures also show the marked reversion in all components which occurred on the omission of thyroid. The chemical data have been plotted arithmetically according to scales representative of the normal range for each variable.

\section{RESULTS}

Cholesterol and basal metabolic rate. Inspection of Table I shows that the patients with most of the symptoms of myxedema, including basal metabolic rates below minus 20, experienced striking relief from symptoms on thyroid dosage of only 1 to 2 grains daily. At the same time the basal metabolic rates rose 14 to 31 per cent to approximately zero in 3 and to minus 15 per cent

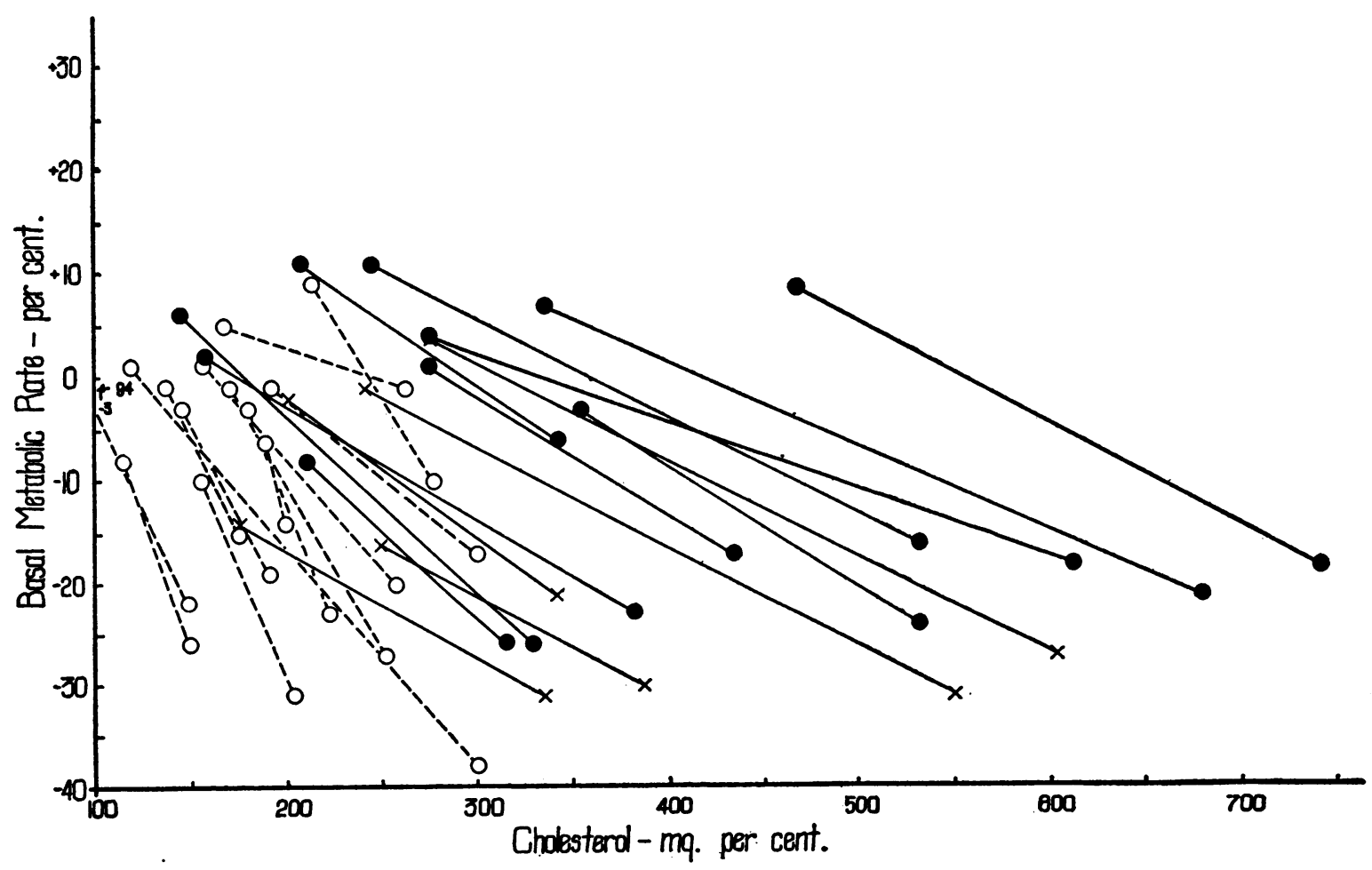

Fig. 2. Direction and Degree of Change in Basal Metabolic Rate and Serum Cholesterol Produced by Thyroid in 29 Patients

Solid circles and solid lines indicate values in patients who improved on thyroid therapy (Table I). Crosses and solid lines indicate values in patients who also improved on thyroid therapy (Table II).

Open circles and broken lines indicate values in patients who did not improve on thyroid therapy (Tables III and IV). 


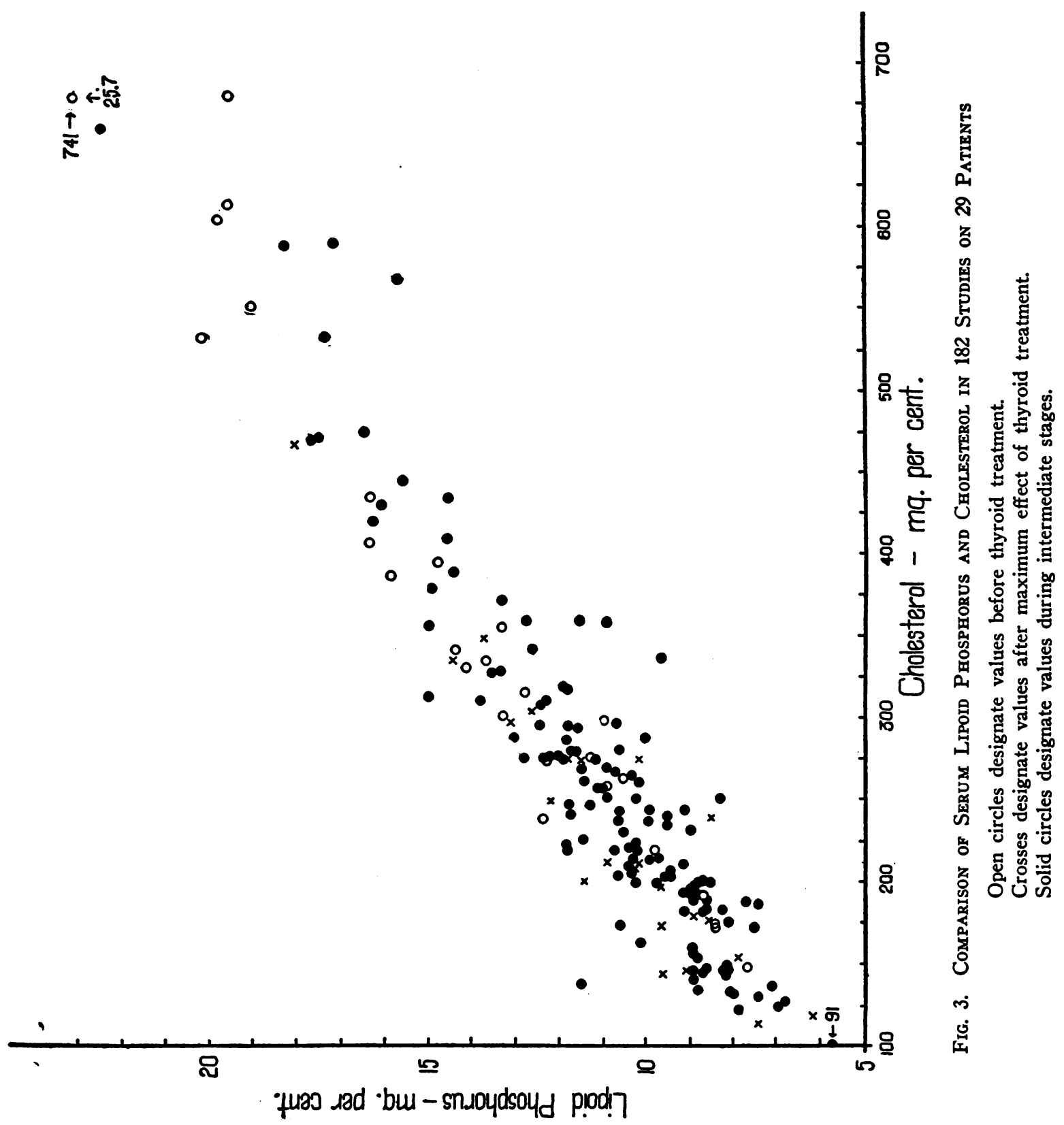




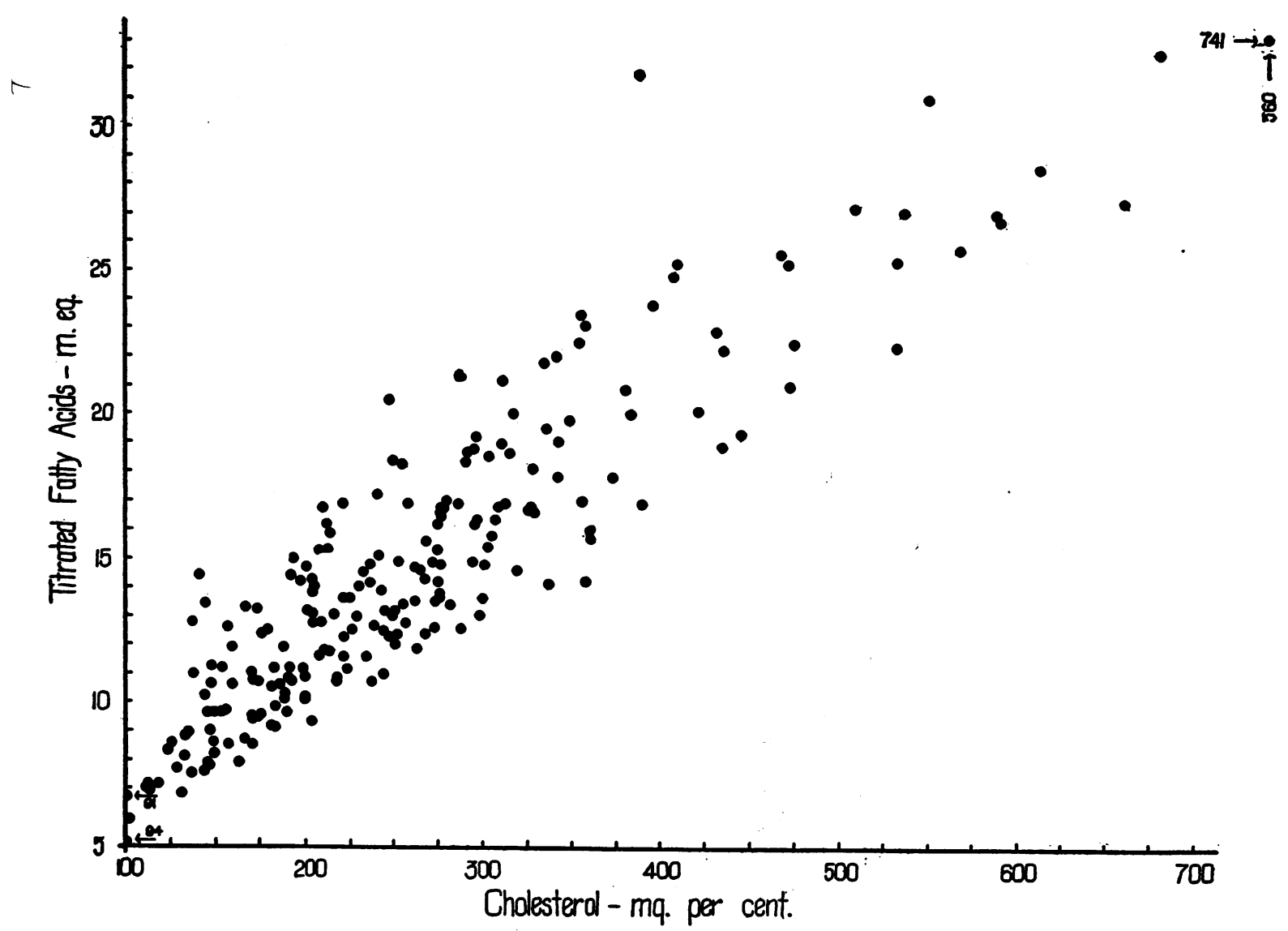

Fig. 4. Comparisons of Serum fatty Acids and Cholesterol in 214 Studies on 29 Patients

in 2. While these changes were taking place the serum cholesterols fell from the abnormally high initial concentrations ranging from 335 to 603 mgm. per cent to the normal range of $275 \mathrm{mgm}$. per cent or less, the lowest being $176 \mathrm{mgm}$. per cent.

The patients included in Table II were relieved by thyroid of the symptoms referable to hypothyroidism almost as completely as those in group 1. But before they were tested in this fashion, there were one or more reasons for determining whether or not hypothyroidism was present in each case. It can be seen in Table II, for example, that the basal metabolic rates of 6 cases ranged from only minus 18 per cent to minus 1 per cent. (While edema was present in 5 patients, there was enough evidence in 3 of chronic nephritis or cardiovascular disease to obscure its significance.) Also, the other symptoms such as dry skin, coarse thin hair, retardation, weakness, and sensitivity to cold, were frequently not marked enough to be helpful in diagnosis. It is therefore noteworthy that the initial cholesterols were all abnormally high; in fact their range of 315 to $741 \mathrm{mgm}$. per cent was similar to that of the myxedematous patients in Table I. The relief of symptoms and the extent of the fall of cholesterol on treatment with $1 / 2$ to $2 \frac{1}{2}$ grains of thyroid also corresponded closely with the group in Table I, with the exception of cases 54183, A33872 and P1536. In these latter patients the symptoms due to hypothyroidism were relieved and their cholesterols fell more than 250 mgm. per cent. Yet, owing to complicating conditions, weakness and other symptoms persisted and the cholesterols remained above normal.

Omission of the thyroid in 4 of the patients in groups 1 and 2 produced a complete reversion in symptoms and a parallel rise in cholesterol, thereby confirming the previous evidence indicat- 
ing that the concentration of serum cholesterol is related to the activity of thyroid substance in the body. The ultimate conclusion was that the patients in groups I and II had hypothyroidism because the therapeutic responses both as to physical signs and cholesterol effect were marked, although the basal metabolic rates were not always very low before treatment.

The patients in Table III were suspected of having hypothyroidism because the basal metabolic rates were definitely below minus 20 per cent and associated with a number of symptoms of hypothyroidism. They did not respond, however, to treatment with thyroid and in this respect differed from the patients in Tables I and II. A comparison of the 3 tables also demonstrates that none of the patients in Table III had cholesterols that were as high as those in I and II. In fact all of the cholesterols were under $259 \mathrm{mgm}$. per cent, with the single exception, P1667, whose cholesterol was 300 mgm. per cent.

A comparison of the patients in Table IV with those in I and II shows again, although less strikingly, that the presence of a low basal metabolic rate and some of the symptoms attributed to hypothyroidism does not indicate that the symptoms will necessarily be relieved by thyroid administration. It is also apparent that these patients like those in Table III have much lower cholesterols and also lower proteins.

These data indicate that the effects of administering thyroid can be foretold more accu-

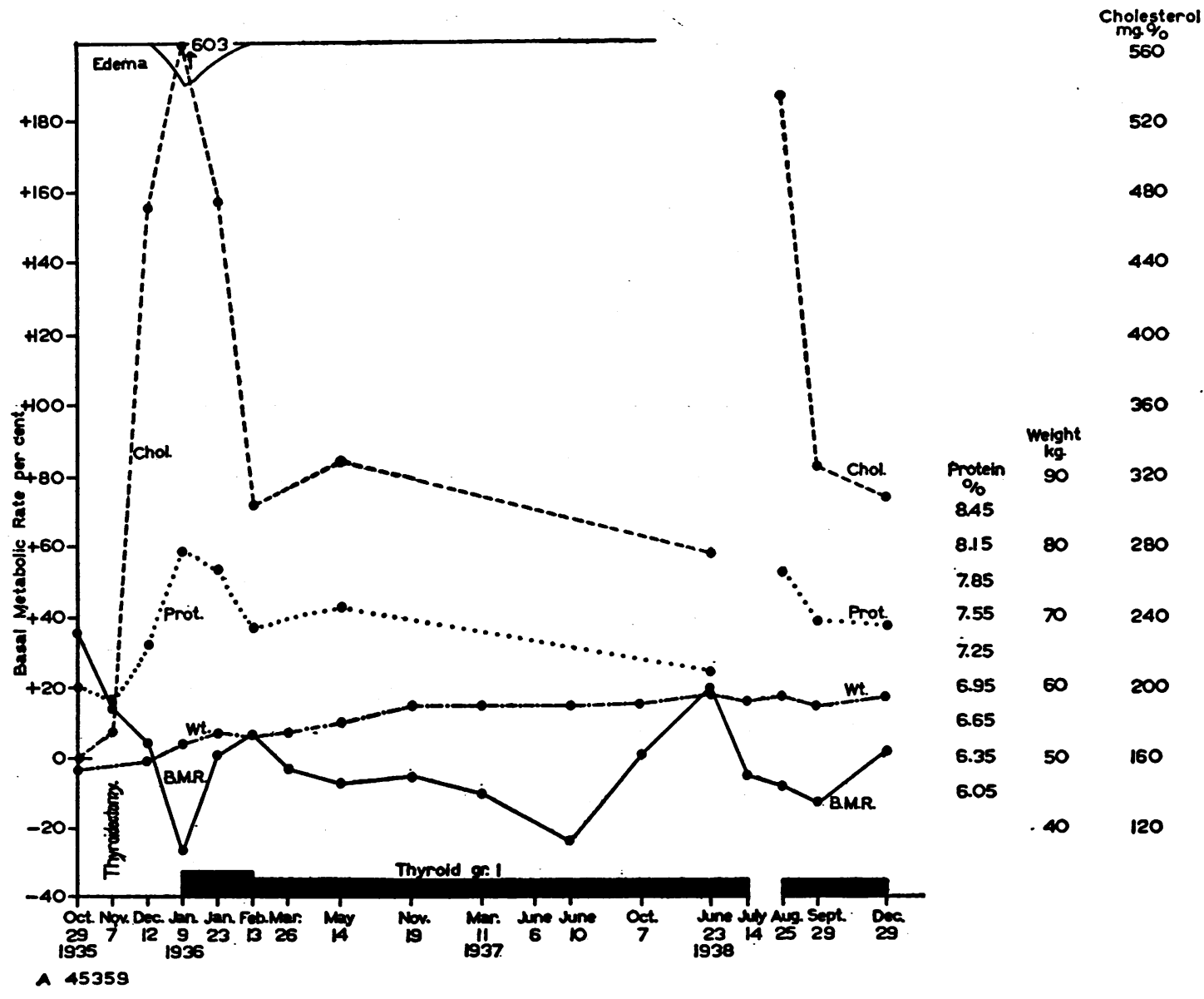

Fig. 5. Relative Changes in Basal Metabolic Rate, Weight, Edema, Serum Cholesterol and ProTEINS of A45359

Thyroid dosage indicated by solid black block; gaps, no thyroid; narrow block, grains 1 ; wide, grains $11 / 2$ per day. 


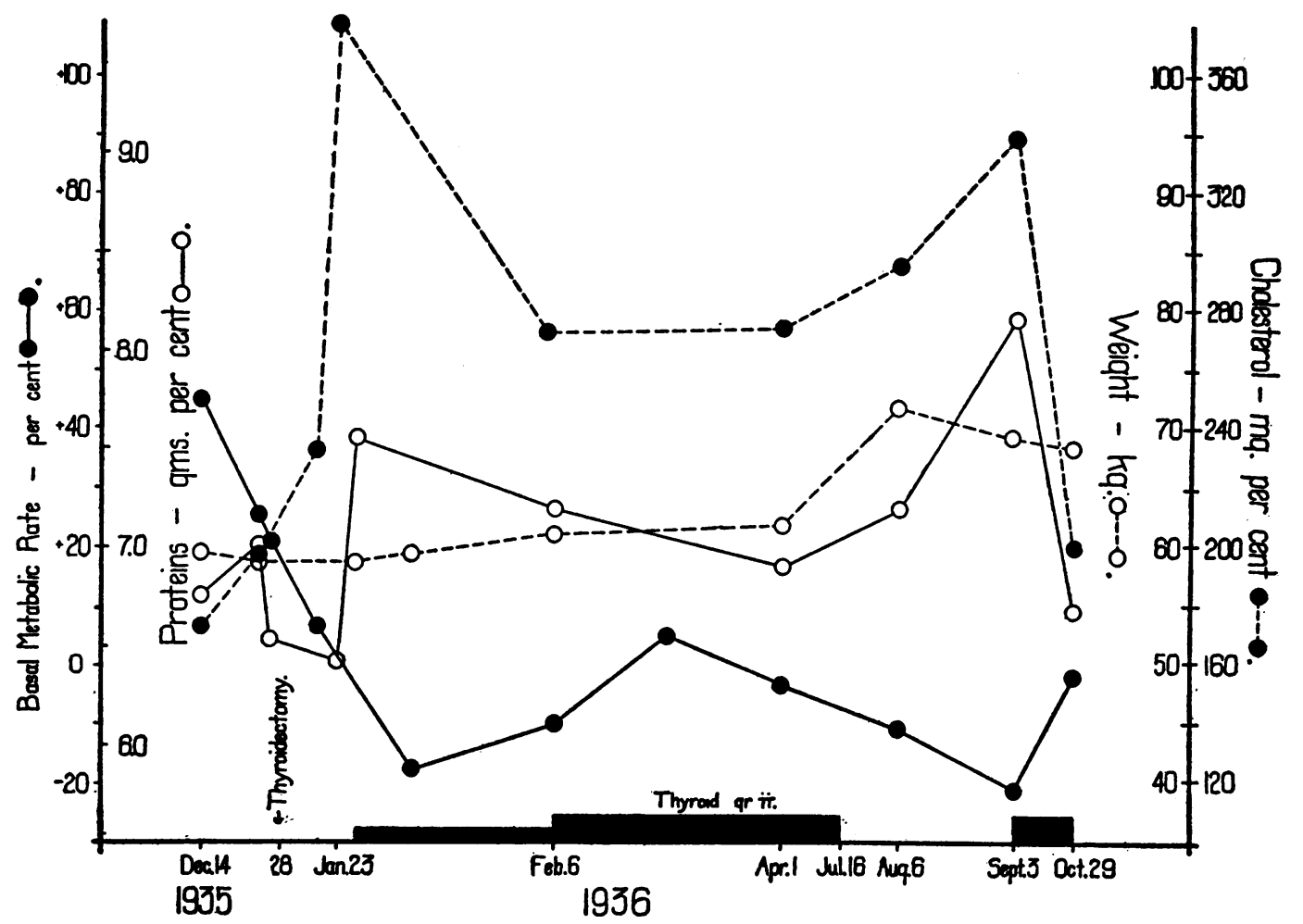

Fig. 6. Relative Changes in Basal Metabolic Rate, Weight, Serum Cholesterol and Proteins of A43137

No edema was observed. Thyroid dosage indicated by solid black block; gaps, no thyroid; narrow block, grains 1 ; wide, grains 2 per day.

rately if, in addition to determination of the basal metabolic rate, the cholesterol is also measured. This point is illustrated in Figure 1 where it can be seen that all of the patients who improved on thyroid, denoted by circles, had initial cholesterols well above $300 \mathrm{mgm}$. per cent, while those who did not, represented by crosses, had far lower amounts with one exception, P1667, who had 300 mgm. per cent.

Furthermore, the serum cholesterol proved to be very sensitive to the administration of thyroid. Inspection of Figure 2 shows that the cholesterol fell after thyroid in all of the patients. However, the fall in cholesterol took place on 1 to 2 grains of thyroid in the myxedematous patients (Tables I and II) while much larger amounts were required in the others (Tables III and IV). The actual magnitude of the decreases in cholesterol is dependent to some extent on the initial level of cholesterol. The relation of the height of the cholesterol to the severity of myxedema is considered later in the discussion. The sensitivity was also apparent when thyroid therapy was omitted and a reversion to the pre-treatment condition occurred. Examples of these responses may be seen in Figures 5,6 and 9. In a number of patients-for example, A45359, Figure 5, A43137, Figure 6-cholesterol changed earlier than the basal metabolic rate.

Lipoid phosphorus. As can be seen in Figure 3 , where all of the determinations on the 4 groups of patients have been plotted, there is essentially a straight line relationship between cholesterol and lipoid phosphorus. This correlation is so close over the whole range that, within narrow limits, the concentration of either component could be predicted from analytical measurement of the other.

Fatty acids. The fatty acids in most of the patients tended to vary with the cholesterol. But, as can be seen in Figure 4 where they have been plotted against cholesterol, the relation was not as 
precise as was that of the phospholipids. It is interesting that the hypothyroid patients, A58944 and A39091, who had fatty acids high in proportion to cholesterol, were those who also had microcytic anemias and some malnutrition. On the other hand, those who had cholesterols particularly high in proportion to the fatty acids, A33872, A67142, P1536, 1, and P1667, all had comparatively low proteins, 7.4 to 6.1 per cent. A67142 and P1536 also had mild forms of chronic nephritis. Furthermore, the fatty acids seemed less responsive to thyroid and in 4 of the non-hypothyroid patients failed to fall with the cholesterol.

Proteins. The serum proteins of the 5 myxedematous patients in Table I were determined before thyroid treatment and in 3 patients after omission of thyroid. Of these 8 determinations of serum proteins without recent thyroid therapy, 7 values were between 7.4 and 8.4 per cent. These values are distinctly higher than would be expected in 5 normal subjects. According to the data of Peters and Eisenman (11), the serum proteins of normal subjects vary from 5.7 to 8.0 per cent and 90 per cent of the values lie between 6.3 and 7.7 per cent. Only 5 of the 11 patients in group 2 had proteins above 7.4 per cent. Although improvement from thyroid administration can be predicted from the initial high level of serum proteins in clear-cut cases of myxedema, it cannot be predicted from the proteins in doubtful cases.

The changes which occurred in the proteins of

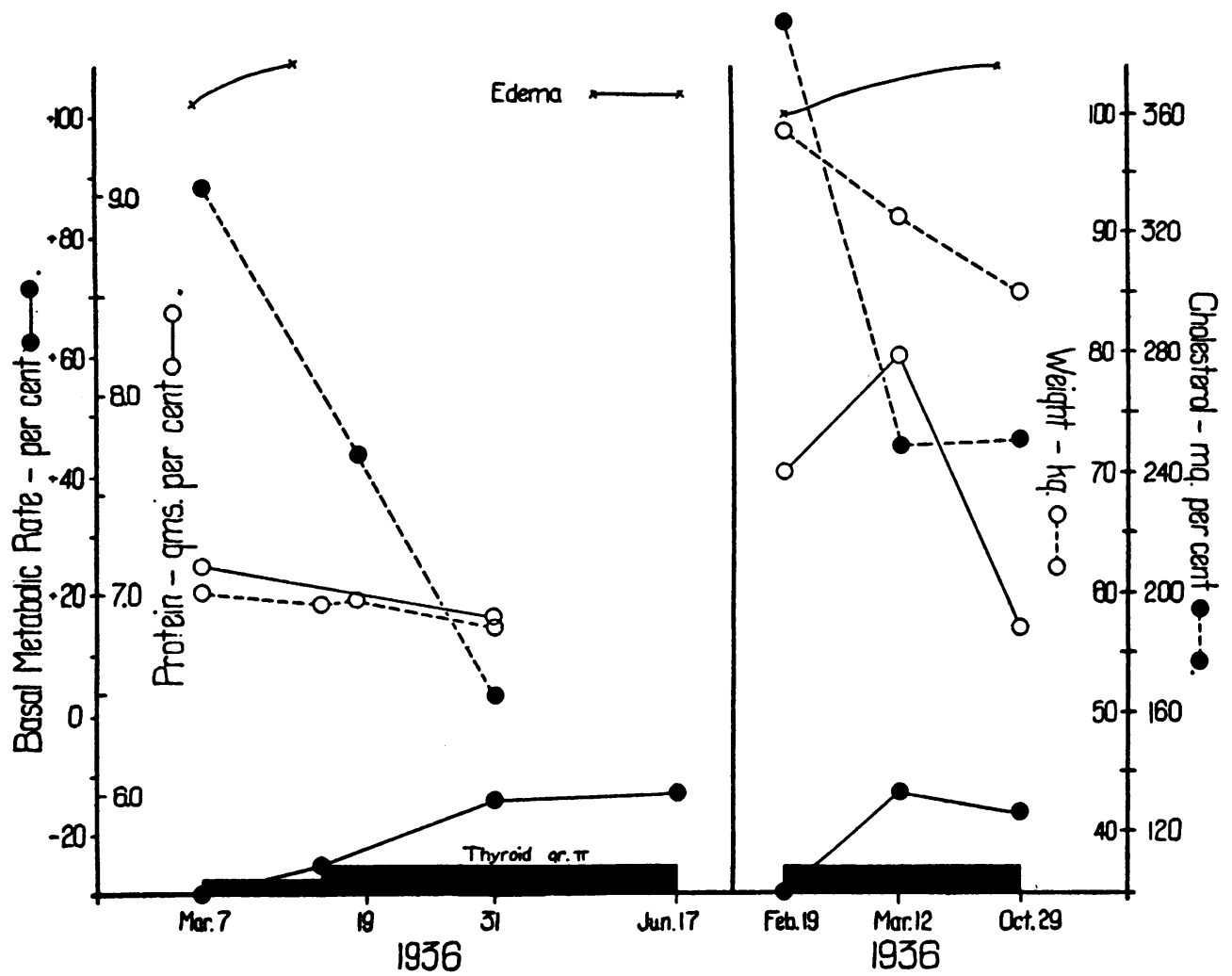

Fig. 7.

FIg. 8.

Fig. 7. Relative Changes in Basal Metabolic Rate, Weight, Edema, Serum Cholesterol ANd Proteins of A62475

Thyroid dosage indicated by solid black block; gaps, no thyroid; narrow block, grains 1; wide, grains 2 per day.

Fig. 8. Relative Changes in Basal Metabolic Rate, Weight, Edema, Serum Cholesterol and Proteins of A58944

Thyroid dosage, grains 2 per day, indicated by wide black block. 


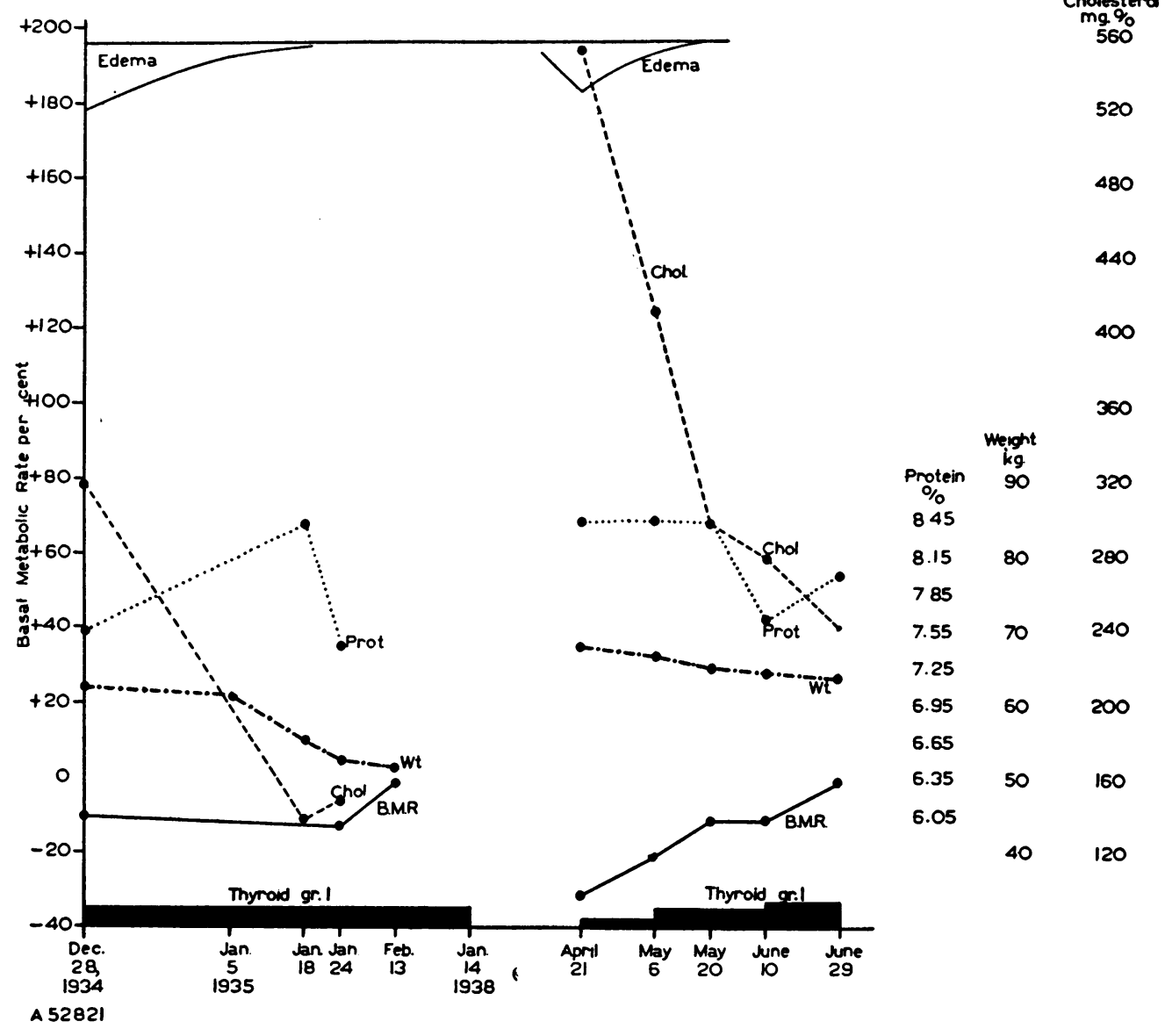

Fig. 9. Relative Changes in Basal Metabolic Rate, Weight, Edema, Serum Cholesterol and Proteins of A52821

Thyroid dosage indicated by black block; gaps, no thyroid; narrow block, grains $1 / 2$; medium, grains 1 ; wide, grains $1 \frac{1 / 2}{2}$ per day.

the 5 myxedematous patients after treatment are illustrated in Figures 5, 6, 7, 8 and 9. In 3 of the 5 patients in group 1 after thyroid administration the proteins fell from 0.2 to 1.4 per cent. In the fourth patient, A58944 (Figure 8), the proteins rose from 7.6 to 8.2 per cent in the face of clinical improvement manifested by a loss in weight, a marked fall in cholesterol and rise in basal metabolic rate. Eight months later, however, when recovery had taken place, the proteins had dropped to 6.8 per cent. The fifth patient, A52821, was anemic and had been on a deficient diet before thyroid therapy. Thyroid administration and a more adequate diet were followed in 21 days by a weight loss of $7 \mathrm{kgm}$., a rise in proteins, marked clinical improvement, fall in lipoids, and rise in basal metabolic rate. Four years later, when the patient felt so well that she omitted thyroid, a reversion in symptoms to the former myxedematous state occurred. Her serum proteins at this time were 8.4 per cent. After 15 days of thyroid ( 0.5 grains daily) her proteins did not change but there was a weight loss of 1 $\mathrm{kgm}$. Thyroid was increased to 1 grain daily and 14 days later the serum proteins were the same, yet loss of weight amounted to $1.6 \mathrm{kgm}$., the basal metabolic rate had risen, cholesterol had fallen, and most of the symptoms of myxedema had gone. It was not until 3 months after treatment was begun that the proteins fell to below 8.0 per cent. In the first 2 patients omission of thyroid produced a rise in serum proteins and resumption of thyroid 
again resulted in a decrease. Further inspection of the charts reveals that the proteins were not regularly affected as rapidly as were serum cholesterol, basal metabolic rate, or symptoms.

In group 2 the serum proteins of A39091, A67142 and P1536 can hardly be included because the first patient suffered from a severe cardiac disorder and the other 2 from low grade chronic nephritis. The serum proteins of 5 of the remaining 8 patients were 0.5 to 1.8 per cent lower after thyroid. Six of the 7 patients in group 3 had a decrease of 0.4 to 0.7 per cent in proteins after thyroid. In group 4, consisting of patients who were given thyroid because of vague symptoms, there is no correlation between serum proteins and thyroid administration.

All the patients in group 1, except A45359, lost weight after the administration of thyroid. In group 2, 5 of the 8 patients without cardiac or renal complications weighed less after thyroid. Two of these, 10670 and 1, had simultaneous diminutions in body weight and in serum proteins. No correlation could be discovered between changes in clinical evidences of edema, including weight loss, and serum proteins.

\section{DISCUSSION}

The serum cholesterol of every patient in the 4 tables fell after the administration of thyroid. Some of these patients, notably A44014, 6, 5253 and P1667, required large doses to effect these results. In Tables III and IV (with the exception of P1667 who was injected intravenously with large doses of thyroxin) the decreases in cholesterol in 8 of the 12 patients were between 11 and $65 \mathrm{mgm}$. per cent. It has been shown previously that serum cholesterol in the same individual varies over a wide range if it is quantitated repeatedly $(18,19,20)$. In our own experience (18) the cholesterol of a normal male studied at intervals for $2 \frac{1}{2}$ years varied from 173 to $239 \mathrm{mgm}$. per cent, and in a normal female studied 4 years the cholesterol varied from 203 to $257 \mathrm{mgm}$. per cent. The fall in cholesterol in patient 6 from 149 to $94 \mathrm{mgm}$. per cent (Table III) may be of more significance than a similar variation in the cholesterol of the normal male from 239 to $173 \mathrm{mgm}$. per cent. It is preferable, therefore, to express the decrease in cholesterol as the per cent of the highest value for the indi- vidual. Percentage decreases in cholesterol in 6 of the 12 patients in Tables III and IV (with omission of P1667) were less than the percentage decrease in the cholesterol of the normal male. It is obvious that, though thyroid invariably lowered the serum cholesterol, the actual diminutions in half the patients in Tables III and IV did not exceed the limits of normal variation.

Examination at frequent intervals of the serum of 3 patients in the third and fourth groups has shown that the decrease in cholesterol was only transient. These 3 patients were an obese male (2) with no clinical signs of myxedema, a hypochondriacal obese female (A6147) 66 years old, and a 27-year-old female (A59140) who developed a unilateral exophthalmos after thyroidectomy. Before deciding, however, that the fall in cholesterol is transient, the size of the dose of thyroid and the amount of increase must be considered. A male patient weighing 182 kilograms showed no reduction in cholesterol after 2 grains of thyroid per day. That the cholesterol might have fallen if the dosage had been increased is suggested by the fact that many of the patients in groups 3 and 4, whose weight did not approach $182 \mathrm{kgm}$. required 2 or more grains of thyroid to reduce the cholesterolemia.

The question as to whether or not the oral administration of thyroid permanently lowers the serum cholesterol of normal, as well as of myxedematous individuals, has been attacked from different angles by many investigators. Page and Farr (21) have recently confirmed earlier observers that thyroid ingestion does not decrease the hypercholesterolemia of nephrosis. Blumgart and coauthors $(22,2)$ have found that, after total ablation of the thyroid for heart disease, serum cholesterol rises. The cholesterolemia of these thyroidectomized patients is usually influenced more markedly by small doses of thyroid than the serum cholesterol of patients without thyroidectomies. Hurxthal (3) gave thyroid to 3 " apparently normal persons" and reported a fall in the blood cholesterol of each. However, 2 of the 3 before thyroid had basals of minus 16 and minus 35 per cent. This seems an unfortunate selection of normal subjects for such an experiment. In the third subject thyroid was only given for 2 weeks, which is too short a time to judge the permanence of the reduction in cholesterol. 
Turner and Steiner (20) reported a sharp drop in serum cholesterol in 10 patients given 30 to 240 milligrams of thyroid per day for 6 weeks. Of their 10 subjects 2 had diabetes, 6 had various forms of heart or vascular disease, and 5 had cholesterols in the control period above $265 \mathrm{mgm}$. per cent so that the individuals can hardly be judged as uncomplicated. It is also impossible to tell whether the cholesterols fell for a short time or persistently throughout the thyroid administration. Cohen and Fierman (23) gave 8 male schizophrenic patients 6 to 15 or 18 grains of Armour's U.S.P. dessicated thyroid for approximately 95 days, and after 67 days repeated the dosage for 69 days. Although no figures for cholesterol are included in the paper, these authors found "no marked displacement of the seasonal trends" of cholesterolemia. Schmidt and Hughes (24) found that thyroxin given orally did not alter the plasma, whole blood total or free cholesterols of normal dogs but did reduce the plasma total and free cholesterol of thyroidectomized dogs. Houchin and Turner (25) noted that, 22 to 30 hours after 5 milligrams of thyroxin had been injected into rabbits, the blood fats decreased. Hurxthal and Perkins (26) have shown that desiccated thyroid diminishes the total cholesterol in the whole bodies of mice. The responses of different animals to thyroid or thyroxin are somewhat difficult to relate to the effect of thyroid on the serum cholesterols of humans because there seem to be certain animals, rabbits or rats fed on normal diets, which do not develop hypercholesterolemia after thyroidectomy $(27,28)$. Also, the effect of thyroxin on serum cholesterol has not been investigated in the present study. It is apparent from the evidence cited here that thyroid, in sufficiently large doses, does lower the serum cholesterol of humans, other than nephrotics, but that in subjects without thyroid deficiency the actual decreases may be small, and that some regulatory reaction may soon permit the cholesterol to return to its normal level. On the other hand, in patients with either spontaneous or post-thyroidectomy myxedema, very small doses of thyroid, $1 / 2$ to 2 grains, rapidly reduce the hypercholesterolemia.

These data demonstrate that the levels of serum cholesterol and other lipoid fractions are markedly increased by a deficiency in thyroid hormone. The concentrations of lipoids may be 2 to 3 times as great as the normal. This increase in serum lipoids greatly exceeds any effects of hemoconcentration due to the state of myxedema. The blood volume in 7 myxedematous patients has been shown by Gibson to be about 15.5 per cent below normal (29)." When thyroid is administered to a patient with hypothyroidism, a fall in lipoids is one of the early changes that takes place. These points are well illustrated in the individual charts of patients in group 1 and in Figures 2, 5, 6, 7, 8 , and 9. The sensitiveness of serum cholesterol to deficiency in thyroid hormone is exemplified by patient A45359, Figure 5. After thyroidectomy this patient was apparently doing well, showed no signs of myxedema, and the basal metabolic rate was plus 4, yet the cholesterol rose to $471 \mathrm{mgm}$. per cent. Only 2 weeks later the symptoms of myxedema began to appear, and in 4 weeks the syndrome was full blown. By this time the cholesterol was $603 \mathrm{mgm}$. per cent, the basal metabolic rate minus 27 per cent, and the proteins 8 per cent. This slow development of clinical symptoms has been pointed out by Means and Lerman (30). On treatment the fall in cholesterol paralleled the remission in symptoms. The marked reversion in symptoms, lipoids and basal metabolic rate to the pre-treatment levels in 3 myxedematous patients, A45359, A43137, A52821, on omission of thyroid, conclusively demonstrates their dependence on the amount of thyroid hormone. These results in general agree with those of Hurxthal and coworkers $(3,31,5)$.

In a patient who has a basal metabolic rate below minus 20 per cent the finding of a cholesterol of over $300 \mathrm{mgm}$. increases the probability of thyroid deficiency. But certain complications such as nephrosis, common bile duct obstruction, or xanthomatosis, which may elevate the serum lipoids, must be ruled out before thyroid administration is advocated. Furthermore, examination of P1667, 85071 and group 4 reveals that there may be other not clearly-defined exceptions. These patients showed no improvement in symptoms on thyroid therapy, although there was a rise in basal metabolic rate and a fall in cholesterol and proteins.

The results indicate therefore that high serum cholesterol is a sufficiently consistent phenomenon in hypothyroidism to warrant its determination as 
a diagnostic aid in doubtful or atypical cases. Of the 16 patients in Tables I and II who improved markedly on $1 / 2$ to $2 \frac{1}{2}$ grain doses of thyroid, only 1 had a cholesterol as low as 316 mgm. per cent. In this latter case the results were moderate because complicating disorders overshadowed the hypothyroid symptoms. However, the most useful criterion suggested by this study lies in the fact that not one of the patients with many symptoms attributable to hypothyroidism, but with serum cholesterol within normal limits, was improved by thyroid. For practical purposes, a serum cholesterol below $275 \mathrm{mgm}$. per cent indicates that in most instances the patient will not be benefitted by thyroid. This criterion must be used with caution, particularly in the case of borderline figures ranging between 275 and 300 mgm. per cent. The present study, for example, shows that no one with a cholesterol below 316 mgm. per cent improved with thyroid therapy. It is conceivable, however, that a patient who in the beginning of the development of hypothyroidism might have had a cholesterol over $350 \mathrm{mgm}$. per cent, would later, as a result of severe malnutrition (32) or liver disease have this reduced to 275 mgm. per cent in spite of the continued progress of the hypothyroid disease. That malnutrition may materially interfere with the development of a high cholesterol in myxedema is suggested by the studies on patient A52821, Figure 9. When first seen she was malnourished and had a microcytic anemia as well as fully-developed myxedema, and her cholesterol was $318 \mathrm{mgm}$. per cent. Subsequently, she made a good recovery on 1 grain of thyroid, but after 3 years of good health stopped taking thyroid. When she returned again with about the same degree of myxedema as during the first study, she was not malnourished and it is noteworthy that her serum cholesterol was $550 \mathrm{mgm}$. per cent in contrast to the previous 318 mgm. per cent. Patients A62475 and A58944 had moderate degrees of microcytic hypochromic anemia, a condition often associated with a reduction in cholesterol. It is therefore not surprising that the severity of the myxedema cannot be shown to be quantitatively proportional to the concentration of cholesterol.

The relation of the serum proteins to the clinical state of the 5 myxedematous patients in group 1 remains obscure. It is evident that the proteins were elevated to high normal or slightly above when the patients were myxedematous, and that they gradually fell as improvement followed the administration of thyroid. But they did not necessarily fall with the disappearance of edema. In the case of A45359, Figure 5, proteins had declined only slightly when the edema had practically disappeared. In patients A52821, Figure 9, and A58944, Figure 8, the proteins actually rose as weight loss occurred, the edema disappeared, and there was striking clinical improvement. In the remaining 2 only did the proteins and weight fall simultaneously. These divergent responses could be explained by Gibson's studies. $\mathrm{He}$ found in 2 cases of myxedema that, after thyroid administration and after increases in basal metabolic rate, the blood volume increased in one patient and remained unchanged in the other (29). In these 2 patients the level of serum proteins would probably not have shown similar changes after thyroid administration.

In 10 instances, in which both albumin and globulin were determined simultaneously with a fall of serum proteins following thyroid, both fractions were about equally implicated 7 times; globulin was more important twice and albumin more important once. Since the 2 patients whose globulin fell more markedly than the albumin had several complications, and since the patient whose albumin fell more than the globulin showed only a small decrease in protein and albumin near the error of the method, only little significance can be attributed to these exceptions. The simultaneous fall in total proteins, albumin and globulin of the 7 patients would imply an increase in blood volume and hydration.

Further investigation may show that although serum proteins are not as sensitive an indicator of deficiency in thyroid hormone as the basal metabolic rate and cholesterol, the finding of values of over 7.7 per cent may constitute an additional and useful criterion of hypothyroidism. However, it is clear from the studies of the patients in group 1 and 2 that many patients with definite myxedema may have low normal proteins, and that a fall in proteins may not occur until some time after clinical improvement, rise in basal metabolic rate, and fall in cholesterol have taken place. One could not expect in clinical cases of this kind an exact correlation between proteins 
and evidences of thyroid activity, because proteins are subject to the influence of so many nutritional factors. The exact relation between proteins and thyroid function could only be elucidated by controlled experiments.

Patients with diminished basal metabolic rates, low serum lipoids, and incapacitating fatigability are still being studied. These patients fall into a different classification than the patients discussed by Hurxthal (4), who has considered the effects of the pituitary and adrenals in lowering the basal metabolic rate. From the study of the patients in groups 3 and 4 , it is apparent that the administration of thyroid does not ameliorate the symptoms of lack of energy and multiple complaints. On the other hand, patients with low basals and low lipoids often are asthenic in physique (33) and are troubled by tension, irritability, tremulousness and insomnia. The administration of thyroid to such persons seems contraindicated, as for example in (6) Table III. This man had found work difficult because of weakness and easy fatigability. When it was discovered that his basal was minus 27 per cent he began to take thyroid. The results were disappointing and the dose was rapidly increased to 4 grains and was maintained for 1 month. As improvement was negligible he tried 6 grains daily. This resulted in tremor and nervousness with no relief of symptoms although the basal metabolic rate had risen to minus 1 per cent. The dose was reduced to 4 grains and maintained for 3 months. He continued to feel as weak as ever. Thyroid was stopped. After a month his basal had fallen to minus 22 per cent, and his weakness and fatigability had not increased. It is of particular interest that the cholesterol was extremely low (149 mgm. per cent) without thyroid, and that with thyroid it was reduced to the remarkable level of $94 \mathrm{mgm}$. per cent which has been found previously only in grave malnutrition, cirrhosis and acute and severe hyperthyroidism.

\section{CONCLUSIONS}

1. The levels of serum cholesterol, phosphatides, and fatty acids are readily affected by changes in the amount of thyroid hormone in the body.

2. Patients with myxedema have remarkably high serum lipoids (cholesterol 335 to $603 \mathrm{mgm}$. per cent). Amelioration in symptoms by administration of 1 to 2 grains of desiccated thyroid is closely paralleled by a fall in lipoids and a rise in basal metabolic rate. The lipoids revert to former high levels with return of symptoms following omission of thyroid therapy. In patients without hypothyroidism thyroid lowers serum cholesterol, but the decreases are not so significant and larger amounts are required.

3. The level of serum cholesterol is a useful tool in determining the presence or absence of hypothyroidism. A serum cholesterol below 275 mgm. per cent practically excludes hypothyroidism and indicates that the administration of thyroid will probably have little or no effect in relieving symptoms.

4. Although the combination of high cholesterol and low basal metabolic rate may be the result of conditions other than hypothyroidism, patients with these findings should be considered as having hypothyroidism until the contrary is proven by their failure to improve after treatment with thyroid.

5. Serum proteins tend to lie above or in the upper part of the normal range in hypothyroidism. The level of proteins could not be consistently correlated with the amount of edema. In many of these patients nutritional and metabolic factors appeared to be more important than changes in water balance in determining proteins.

It would have been impossible to collect this material if it had not been for the clinical services of Dr. Paul Lavietés and Dr. Alexander Winkler under whose care were many of the patients.

\section{BIBLIOGRAPHY}

1. Bronstein, I. P., Studies in cretinism and hypothyroidism in childhood. I. Blood cholesterol. J. A. M. A., 1933, 100, 1661 .

2. Gilligan, D. R., Volk, M. C., Davis, D., and Blumgart, H. L., Therapeutic effect of total ablation of normal thyroid on congestive heart failure and angina pectoris. VIII. Relationship between serum cholesterol values, basal metabolic rate and clinical aspects of hypothyroidism. Arch. Int. Med., 1934, 54, 746.

3. Hurxthal, L. M., Blood cholesterol and thyroid disease. III. Myxedema and hypercholesteremia. Arch. Int. Med., 1934, 53, 762.

4. Hurxthal, L. M., Blood cholesterol and hypometabolism; suprarenal and pituitary deficiency, obesity and miscellaneous conditions. Arch. Int. Med., 1934, 53, 825. 
5. Mason, R. L., Hunt, H. M., and Hurxthal, L. M., Blood cholesterol values in hyperthyroidism and hypothyroidism-their significance. New England J. Med., 1930, 203, 1273.

6. Gardner, J. A., and Gainsborough, H., The relationship of plasma cholesterol and basal metabolism. Brit. M. J., 1928, 2, 935.

7. Boyd, E. M., and Connell, W. F., Thyroid disease and blood lipids. Quart. J. Med., 1936, N.S. 5, 455.

8. Boyd, E. M., and Connell, W. F., Plasma lipids in diagnosis of mild hypothyroidism. Quart. J. Med., 1937, 6, 467.

9. Grabfield, G. P., and Campbell, A. G., Note on relation between blood cholesterol and basal metabolic rate. New England J. Med., 1931, 205, 1148.

10. McGee, L. C., Blood cholesterol in disturbances of basal metabolic rate. Annals Int. Med., 1935, 9, 728.

11. Peters, J. P., and Eisenman, A. J., Serum proteins in diseases not primarily affecting cardiovascular system or kidneys. Am. J. M. Sc., 1933, 186, 808.

12. Bruckman, F. S., D'Esopo, L. M., and Peters, J. P., Plasma proteins in relation to blood hydration. IV. Malnutrition and serum proteins. J. Clin. Invest., 1930, 8, 577.

13. Bogdanovitch, S. B., and Man, E. B., Effects of castration, theelin, testosterone and antuitrin-S on lipoids of blood, liver and muscle of guinea pigs. Am. J. Physiol., 1938, 122, 73.

14. Man, E. B., and Peters, J. P., Gravimetric determination of serum cholesterol adapted to Man and Gildea fatty acid method, with note on estimation of lipoid phosphorus. J. Biol. Chem., 1933, 101, 685.

15. Man, E. B., Note on stability and quantitative determination of phosphatides. J. Biol. Chem., 1937, 117, 183.

16. Man, E. B., and Gildea, E. F., Modification of Stoddard and Drury titrimetric method for determination of fatty acids in blood serum. J. Biol. Chem., 1932, 99, 43.

17. Man, E. B., and Gildea, E. F., Notes on extraction and saponification of lipids from blood and blood serum. J. Biol. Chem., 1937, 122, 77.

18. Man, E. B., and Gildea, E. F., Variations in lipemia of normal subjects. J. Biol. Chem., 1937, 119, 769.

19. Sperry, W. M., Concentration of total cholesterol in blood serum. J. Biol. Chem., 1937, 117, 391.

20. Turner, K. B., and Steiner, A., Long term study of variation of serum cholesterol in man. J. Clin. Invest., 1939, 18, 45.

21. Page, I. H., and Farr, L. E., Influence of high and low fat diets and thyroid substance on plasma lipids of nephrotic patients. J. Clin. Invest., 1936, 15, 181.

22. Blumgart, H. L., and Davis, D., Hypothyroidism induced by complete removal of normal thyroid gland in treatment of chronic heart disease. Endocrinology, 1934, 18, 693.

23. Cohen, L. H., and Fierman, J. H., Metabolic, cardiovascular and biochemical changes associated with experimentally induced hyperthyroidism in schizophrenia. Endocrinology, 1938, 22, 548.

24. Schmidt, L. H., and Hughes, H. B., Free and total cholesterol content of whole blood and plasma as related to experimental variations in thyroid activity. Endocrinology, 1938, 22, 474.

25. Houchin, O. B., and Turner, C. W., The relation of the pituitary to blood lipids. Endocrinology, 1939, 24, 638.

26. Hurxthal, L. M., and Perkins, H. J., The destruction of total body cholesterol by the feeding of desiccated thyroid. Lahey Clinic Bull., 1938, 1, 19.

27. Leonard, S. L., The blood cholesterol in thyroidectomized rats as related to the effectiveness of gonadotropic hormones. Endocrinology, 1939, 24, 679.

28. Turner, K. B., Present, C. H., and Bidwell, E. H., Role of thyroid in regulation of blood cholesterol of rabbits. J. Exper. Med., 1938, 67, 111.

29. Gibson, J. G., 2d, and Harris, A. W., Clinical studies of blood volume. V. Hyperthyroidism and myxedema. J. Clin. Invest., 1939, 18, 59.

30. Means, J. H., and Lerman, J., The symptomatology of myxedema; its relation to metabolic levels, time intervals and rations of thyroid. Trans. Assoc. Am. Physicians, 1934, 49, 214.

31. Hurxthal, L. M., and Hunt, H. M., Clinical relationships of blood cholesterol with summary of our present knowledge of cholesterol metabolism. Annals Int. Med., 1935, 9, 717.

32. Man, E. B., and Gildea, E. F., Serum lipoids in malnutrition. J. Clin. Invest., 1936, 15, 203.

33. Gildea, E. F., Kahn, E., and Man, E. B., Relationship between body build and serum lipoids and discussion of these qualities as pyknophilic and leptophilic factors in structure of personality. Am. J. Psychiat., 1936, 92, 1247. 